\title{
ANALISIS PENGUNGKAPAN LAPORAN KEUANGAN PEMERINTAH KOTA MANADO TAHUN 2015
}

\author{
Andi Lombar Dini ${ }^{1}$, Harijanto Sabijono ${ }^{2}$, Natalia Gerungai ${ }^{3}$ \\ ${ }^{1,2,3}$ Jurusan Akuntansi, Fakultas Ekonomi dan Bisnis, Universitas Sam Ratulangi, Jl. Kampus Bahu, Manado, \\ 95115, Indonesia
}

E-mail : andilombar@rocketmail.com

\begin{abstract}
The government has the power to collect people's income and use it to finance these activities in order to provide services to the public. Governments should be responsible for such activities in a transparent manner, in accountability to make a financial report where the financial statements will be assessed by the BPK to be given an audit opinion. On Wednesday 22 June 2016, the manado city government represented by the mayor of Manado received LHP (Laporan Hasil Pemeriksaan) from the State Audit Agency Republic of Indonesia (BPK$R I)$ representative of North Sulawesi on the financial statements of Manado city government in 2015. However, from several studies, there are still some reports that have not fully disclosed the information that should be disclosed in the financial statements. This research method using qualitative method. The results of this study found the disclosure level of financial statements of Manado city government in 2015 was $52.94 \%$, it explains that the financial statements of Manado municipal government have not fulfilled all the disclosure items in PP N0.71 Year 2010 on Government Accounting Standards.
\end{abstract}

Keywords : Disclosure, Opinion, Public

\section{PENDAHULUAN}

Pemerintah memiliki kekuatan untuk mengumpulkan pendapatan masyarakat dan menggunakannya untuk membiayai kegiatan tersebut guna memberikan pelayanan kepada publik. Pemerintah harus bertanggung jawab atas kegiatan tersebut secara transparan (Arifin, 2013). Seperti yang dikatakan Setiono (2016) dalam penelitiannya, dia menemukan praktik akuntabilitas publik di Indonesia masih di legitimasi pragmatis. Laporan keuangan dan audit laporan ini dikembangkan hanya untuk pengguna utama laporan keuangan. Mereka tidak disiapkan untuk kepentingan masyarakat umum, DPR dan pemerintah sebagai representasi dari masyarakat belum mengembangkan budaya tata kelola laporan keuangan dan audit untuk memastikan bahwa praktek akuntabilitas di Indonesia menyajikan informasi yang benar atau adil yang diharapkan oleh masyarakat. Masyarakat membutuhkan penyajian atau pengungkapan informasi tentang seberapa efektif pemerintah dalam menggunakan dana negara untuk memenuhi kewajiban mereka sebagaimana diatur dalam banyak hukum yang mengatur operasi dari pemerintah.

Pelaporan keuangan tentunya harus mengikuti standar yang berlaku serta prinsip prinsip akuntansi yang sudah ada. Peraturan Pemerintah Nomor 71 Tahun 2010 Tentang Standar Akuntansi Pemerintahan Berbasis Akrual dalam kerangka konseptualnya menjelaskan prinsip akuntansi dan pelaporan keuangan dimaksudkan sebagai ketentuan yang dipahami dan ditaati oleh pembuat standar dalam menyusun standar, penyelenggara akuntansi dan pelaporan keuangan dalam melakukan kegiatannya serta pengguna laporan keuangan dalam memahami laporan keuangan yang disajikan. Salah satu prinsip yang dijelaskan dalam Standar Akuntansi Pemerintahan (SAP) adalah prinsip pengungkapan lengkap.

Indonesia, merupakan negara yang mempunyai sumber daya yang begitu melimpah. Indonesia juga memiliki pulau yang begitu banyak, tidak heran Indonesia juga mempunyai 
banyak kota. Masing - masing kota tersebut memiliki pemerintahan yang juga diwajibkan melakukan pengelolaan keuangan, dengan melakukan pelaporan keuangan untuk setiap daerah. Salah satu dari sekian kota di Indonesia adalah Manado. Dari sekian banyak kota yang membuat laporan keuangan, Manado adalah salah satu kota yang mendapatkan penilaian Wajar Tanpa Pengecualian (unqualified opinion). Pada tahun 2016 Pemerintah Kota Manado menerima opini WTP (Wajar Tanpa Pengecualian) yang menunjukkan bahwa tingkat pengungkapan laporan keuangan pemerintah daerah memiliki kualitas baik. Menurut Budiarso (2018) Hasil pemeriksaan BPK memiliki hubungan dengan tingkat akuntabilitas temuan laporan keuangan pemerintah daerah.

\section{TINJAUAN PUSTAKA}

\subsection{Akuntansi}

Menurut Pontoh (2013 : 1), akuntansi pada umumnya sering disebut sebagai bahasa bisnis, dan dapat terlihat dalam beberapa definisi berikut ini :

a. Akuntansi adalah sebuah sistem informasi yang mengukur aktivitas bisnis, pemrosesan data menjadi laporan, dan mengkomunikasikan hasilnya pada para pengambil keputusan.

b. Akuntansi adalah sebuah sistem informasi yang menyediakan laporan - laporan kepada para pengguna mengenai aktivitas ekonomi dan kondisi bisnis - bisnis yang ada.

c. Akuntansi meliputi 3 (tiga) aktivitas dasar - identifikasi, pencatatan, dan mengkomunikasikan peristiwa ekonomi dari sebuah organisasi kepada para pengguna yang berkepentingan.

d. Akuntansi adalah sebuah sistem informasi yang dirancang oleh sebuah organisasi untuk mengidentifikasi (analisis, mencatat, dan meringkas) aktivitas - aktivitas yang mempengaruhi kondisi dan kinerja keuangannya, kemudian mengkomunikasikan hasilnya kepada para pengambil keputusan, baik dari internal maupun eksternal organisasi.

\subsection{Akuntansi Pemerintahan}

Menurut Mursyidi (2013 : 1), akuntansi pemerintahan (govermental acoounting) banyak yang menyatakan merupakan terminologi lama. Pada perkembangannya bergeser ke istilah akuntansi sektor publik. Istilah baru ini didasarkan pada pelebaran wilayah kajian dari akuntansi nirlaba, dimana akuntansi pemerintahan merupakan mekanisme akuntansi yang memproses transaksi keuangan yang berkaitan dengan pengelolaan keuangan negara baik tingkat pusat maupun tingkat daerah. Sementara akuntansi sektor publik meluas pada semua entitas yang bertujuan untuk kesejahteraan masyarakat, misalnya yayasan sosial, lembaga swadaya masyarakat (LSM) dan proyek - proyek kerjasama sektor publik dan swasta.

\subsection{Laporan Keuangan Pemerintah}

Laporan keuangan sektor publik merupakan respresentasi terstruktur dari posisi keuangan akibat transaksi yang dilakukan. Tujuan umum pelaporan keuangan sektor publik adalah menyediakan informasi untuk pengambilan keputusan dan mendemonstrasikan akuntabilitas entitas atas sumber daya yang dipercayakan dengan menyediakan informasi mengenai sumber-sumber alokasi dan penggunaan sumber-sumber daya finansial, menyediakan informasi mengenai bagaimana entitas mendanai aktivitasnya dan memenuhi persyaratan kasnya, menyediakan informasi tentang kondisi keuangan suatu entitas dan perubahan didalamnya, serta menyediakan informasi menyeluruh yang berguna dalam mengevaluasi kinerja entitas atas hal biaya jasa, efesiensi dan pencapaian tujuan (Kema, 2013).

\subsection{Komponen Laporan Keuangan}

Dalam paragraph 28 Standar Akuntansi Pemerintahan berbasis akrual yang diatur dalam Peraturan Pemerintah Tahun 2010 dijelaskan bahwa Laporan keuangan pokok terdiri dari: 
a. Laporan Realisasi Anggaran (LRA);

b. Laporan Perubahan Saldo Anggaran Lebih (Laporan Perubahan SAL);

c. Neraca;

d. Laporan Operasional (LO);

e. Laporan Arus Kas (LAK);

f. Laporan Perubahan Ekuitas (LPE);

g. Catatan atas Laporan Keuangan (CaLK).

\subsection{Pengungkapan Laporan Keuangan}

Pengungkapan lengkap (full disclosure) Laporan keuangan pemerintah dijelaskan dalam PP 71 Tahun 2010 yaitu menyajikan secara lengkap informasi yang dibutuhkan oleh pengguna. Informasi yang dibutuhkan pengguna laporan keuangan dapat ditempatkan pada lembar muka (on the face) laporan keuangan atau Catatan atas Laporan Keuangan. Menurut Medynatul (2017) salah satu kriteria pemeriksaan atas laporan keuangan, yang dilakukan dalam rangka memberikan pendapat / opini atas kewajaran informasi keuangan, yang disajikan dalam laporan keuangan salah satunya berdasarkan pada pengungkapan yang lengkap (full disclosure). Oleh karena itu pengungkapan (disclosure) merupakan hal yang sangat penting dalam pemeriksaan untuk mengeluarkan opini atas laporan keuangan tersebut. Penelitian ini penting dilakukan sebagai upaya perbaikan laporan keuangan pemerintah untuk mencapai target pemerintah. Secara konseptual, pengungkapan merupakan bagian integral dari pelaporan keuangan. Selanjutnya, menurut Medynatul (2017) secara teknis, pengungkapan merupakan langkah akhir dalam proses akuntansi yaitu penyajian informasi dalam bentuk seperangkat penuh statement keuangan. Berikut merupakan jenis pengungkapan dalam hubungannya dengan persyaratan yang ditetapkan standar menurut Suwardjono yang dikutip oleh Medynatul (2017) :

a. Pengungkapan wajib merupakan pengungkapan minimum yang disyaratkan oleh standar akuntansi yang berlaku.

b. Pengungkapan sukarela merupakan pengungkapan butir-butir yang dilakukan sukarela oleh perusahaan tanpa diharuskan oleh peraturan yang berlaku.

\section{METODE PENELITIAN}

\subsection{Jenis Penelitian}

Jenis penelitian yang digunakan dalam penelitian ini adalah kualitatif. Data dalam penelitian ini merupakan data berupa laporan keuangan Pemerintah Kota Manado Tahun 2015, yang diambil dari Badan Pengelola Keuangan dan Aset Daerah (BKPAD) Pemerintah Kota Manado, dimana Badan Pengelolaan Keuangan dan Aset Daerah Pemerintah Kota Manado berfungsi sebagai pengelola keuangan pemerintah kota.

\subsection{Waktu dan Tempat Penelitian}

Penelitian ini mengambil data di Badan Pengelolaan Keuangan dan Aset Daerah (BPKAD) Pemerintah Kota Manado, yang beralamat di Jl. Balai Kota No. 1, Tikala, Kota Manado, Sulawesi Utara. Waktu penelitiam dilaksanakan selama 1 bulan yaitu pada awal bulan Maret sampai akhir bulan Maret 2018.

\section{3. $\quad$ Metode Analisis}

Dalam penelitian ini peneliti akan mendapatkan data berupa laporan keuangan pemerintah kota manado tahun 2015. Peneliti juga akan mengumpulkan data standar pengungkapan yang berasal dari Standar Akuntansi Pemerintahan (SAP) yang terdapat dalam PP No.71 Tahun 2010. Kemudian, peneliti akan menganalisis laporan keungan pemerintah kota manado, apakah pengungkapan laporan keuangan pemerintah kota manado sudah sesuai dengan standar yang ada. 


\section{HASIL ANALISIS DAN PEMBAHASAN}

\subsection{Gambaran Umum Kota Manado}

Asal mula Kota Manado menurut legenda dulu berasal dari "Wanua Wenang" sebutan penduduk asli Minahasa. Wanua Wenang telah ada sekitar abad XIII dan didirikan oleh Ruru Ares yang bergelar Dotulolong Lasut yang saat itu menjabat sebagai Kepala Walak Ares,dikenal sebagai Tokoh pendiri Wanua Wenang yang menetap bersama keturunannya. Versi lain mengatakan bahwa Kota Manado merupakan pengembangan dari sebuah negeri yang bernama Pogidon. Kota Manado diperkirakan telah dikenal sejak abad ke-16. Menurut sejarah, pada abad itu jugalah Kota Manado telah didatangi oleh orang-orang dari luar negeri. Nama "Manado" daratan mulai digunakan pada tahun 1623 menggantikan nama "Pogidon" atau "Wenang". Kata Manado sendiri merupakan nama pulau disebelah pulau Bunaken, kata ini berasal dari bahasa daerah Minahasa yaitu Mana rou atau Mana dou yang dalam bahasa Indonesia berarti "di jauh". Pada tahun itu juga, tanah Minahasa-Manado mulai dikenal dan populer di antara orang-orang Eropa dengan hasil buminya. Hal tersebut tercatat dalam dokumen-dokumen sejarah.

Kota Manado terletak di ujung jazirah utara pulau Sulawesi, pada posisi geografis $124^{\circ} 40^{\prime}-124^{\circ} 50^{\prime} \mathrm{BT}$ dan $1^{\circ} 30^{\prime}-1^{\circ} 40^{\prime} \mathrm{LU}$. Iklim di kota ini adalah iklim tropis dengan suhu rata-rata $24^{\circ}-27^{\circ} \mathrm{C}$. Curah hujan rata-rata $3.187 \mathrm{~mm} /$ tahun dengan iklim terkering di sekitar bulan Agustus dan terbasah pada bulan Januari. Intensitas penyinaran matahari rata-rata 53\% dan kelembaban nisbi $\pm 84 \%$. Luas wilayah daratan adalah 15.726 hektare. Manado juga merupakan kota pantai yang memiliki garis pantai sepanjang 18,7 kilometer. Kota ini juga dikelilingi oleh perbukitan dan barisan pegunungan. Wilayah daratannya didominasi oleh kawasan berbukit dengan sebagian dataran rendah di daerah pantai. Interval ketinggian dataran antara 0-40\% dengan puncak tertinggi di gunung Tumpa.

\subsection{Hasil Penelitian}

Analisis terhadap tingkat pengungkapan laporan keuangan ini dilakukan dengan mengacu pada standar yang ada. Pemerintah Indonesia dalam pengelolaan keuangannya menggunakan beberapa peraturan, salah satunya Peraturan Pemerintah No.71 Tahun 2010 tentang Standar Akuntansi Pemerintahan berbasis Akrual. Dalam Standar Akuntansi Pemerintahan, sudah ditetapkan dan diatur mengenai penyajian laporan keuangan dan prinsip - prinsip yang digunakan. Dalam paragraph 28 Standar Akuntansi Pemerintahan berbasis akrual yang diatur dalam Peraturan Pemerintah Tahun 2010 dijelaskan bahwa Laporan keuangan pokok terdiri dari:

a. Laporan Realisasi Anggaran (LRA);

b. Laporan Perubahan Saldo Anggaran Lebih (Laporan Perubahan SAL);

c. Neraca;

d. Laporan Operasional (LO);

e. Laporan Arus Kas (LAK);

f. Laporan Perubahan Ekuitas (LPE);

g. Catatan atas Laporan Keuangan (CaLK).

Selain itu, di dalam Standar Akuntansi Pemerintahan juga sudah menetapkan mengenai item - item pengungkapan wajib yang harus diungkapkan oleh pemerintah dalam laporan keaungan pemerintah. Item - item inilah yang nantinya akan membantu penulis untuk mengetahui apakah laporan keuangan pemerintah sudah memenuhi standar pengungkapan. Item - item tersebut diambil dari Standar Akuntansi Pemerintahan (SAP) berjumlah 34 item, yang terdiri dari 3 item akunransi persediaan, 6 item akuntansi investasi, 12 item akuntansi aset tetap, 5 item akuntansi konstruksi dalam pengerjaan, dan 8 item akuntansi kewajiban.

Dengan daftar item tersebut peneliti kemudian meneliti laporan keungan pemerintah kota manado apakah sudah memenuhi standar dari daftar item - item pengungkapan tersebut. 
Dalam penelitian ini peneliti mengukur tingkat pengungkapan dengan membandingkan itemitem yang diungkapkan laporan keuangan yang dihasilkan oleh pemerintah kota manado dengan item-item yang harus diungkapkan dalam laporan keuangan pemerintah daerah dengan mengacu pada Peraturan Pemerintah No.71 Tahun 2010 tentang Standar Akuntansi Pemerintah mengunakan Compliance Indexs (Indeks Kepatuhan) seperti yang digunakan oleh Medynatul (2017). Skor indeks pengungkapan untuk setiap pemerintah daerah Indonesia dalam sampel akhir kemudian dihitung sebagai rasio dari total skor diberikan kepada pemerintah daerah dibagi dengan jumlah maksimum item yang berlaku untuk entitas. Setiap item yang diperlukan pada checklist berkode "1" jika diungkapkan dan "0" jika item tersebut tidak diungkapkan. Kemudian, penghitungan tingkat pengungkapan akan menggunakan rumus seperti yang digunakan pada penelitian terdahulu, seperti yang digunakan oleh Izzati (2017) sebagai berikut :

\section{Tingkat Pengungkapan Laporan Keuangan :}

$$
\frac{\text { Jumlah item dalam laporan keuangan }}{\text { Total iem yang harus diungkapkan }} \text { x } 100
$$

Dari hasil penelitian diperoleh hasil berupa pengungkapan laporan keuangan. Dari 34 item pengungkapan yang seharusnya diungkapkan, peneliti mendapati 16 item yang tidak diungkapkan, dan sisanya sebanyak 18 item telah diungkapkan dalam laporan keuangan pemerintah kota manado. Berdasarkan hasil item pengungkapan peneliti menghitung tingkat pengungkapan menggunakan rumus untuk menghitung tingkat pengungkapan laporan keuangan yang diperoleh dari penelitian terdahulu, sebagai berikut :

$$
\frac{18}{34} \times 100=52,94 \%
$$

\subsection{Pembahasan}

Jika dilihat dari tingkat pengungkapan, Pemerintah Kota Manado sudah melaksanakan lebih dari setengah standar item pengungkapan yang ada. Pengungkapan yang disajikan dalam laporan keuangan Pemerintah Kota Manado menunjukkan persentase 52,94\%, yang mengartikan pengungkapan yang diungkapkan Pemerintah Kota Manado belum sepenuhnya memenuhi standar yang ada dalam Peraturan Pemerintah Nomor 71 Tahun 2010 tentang Standar Akuntansi Pemerintahan. Dalam Neraca, pengungkapan yang ada hanya menggambarkan informasi secara umum tentang rincian dari jenis akun pada Neraca dan rincian lebih lanjut pada catatan atas laporan keuangan, sedangkan untuk kebijakan akuntansi yang digunakan, masih ada yang belum diungkapkan di dalam Catatan atas Laporan Keuangan. Adapun item - item yang tidak diungkapkan dalam laporan keuangan Pemerintah Kota Manado dikarenakan pada tahun 2015 belum adanya pengaturan lebih lanjut mengenai seberapa luas informasi yang harus diungkapkan atau informasi prioritas yang menjadi keharusan dan informasi mana yang dianjurkan, karena tahun 2015 masih dalam masa penyesuaian bagi Pemerintah Kota Manado dalam menerapkan perubahan peraturan yang ada, dari PP No.24 Tahun 2005 yang menggunakan basis kas menuju akrual yang diganti menjadi PP No.71 Tahun 2010 yang sudah menggunakan basis akrual secara penuh.

Dari hasil ini menjelaskan bahwa meskipun Pemerintah Kota Manado mendapatkan opini WTP (unqualified opinion) dari BPK, bukan berarti pengungkapan laporan keuangan pemerintah kota manado telah mengungkapkan semua item pengungkapan yang ada, hal tersebut dapat dilihat pada table 4.2 yang menunjukan bahwa item yang diungkapkan sebanyak 18 item dari 34 item yang seharusnya diungkapkan. Hal ini sesuai dengan penelitian terdahulu yang dilakukan oleh Izzati (2017) yang menyimpulkan bahwa temuan 
audit tidak berpengaruh terhadap tingkat total pengungkapan laporan keuangan dan pengungkapan finansial. Hal serupa juga dilakukan oleh Adhariani (2014) memperjelas bahwa tingkat pengungkapan laporan keuangan itu tidak mempengaruhi opini yang diberikan oleh BPK RI. Opini WTP merupakan opini terbaik tidak hanya dihasilkan oleh kabupaten yang memiliki nilai tingkat pengungkapan laporan keuangan yang tinggi, bahkan nilai LKPD yang mendapat opini WTP ada yang lebih rendah daripada LKPD yang mendapat opini Wajar Dengan Pengecualian (WDP) atau TMP. Selain itu, dari hasil wawancara penelitian yang dilakukan Susilo (2015) pada auditor pemeriksa di BPK-RI menjelaskan bahwa pemberian opini Wajar Tanpa Pengecualian bukan hanya dipengaruhi oleh tingkat pengkapan laporan keuangan, ada beberapa pertimbangan yang mempengaruhi opini audit yaitu tingkat materialitas terhadap temuan pengendalian internal dan kepatuhan terhadap peraturan perundang - undangan.

\section{KESIMPULAN DAN SARAN}

\subsection{Kesimpulan}

Berdasarkan hasil penelitian dan pembahasan mengenai tingkat pengungkapan laporan keuangan pemerintah kota manado, dapat disimpulkan bahwa pengungkapan laporan keuangan pemerintah kota manado dapat dikatakan belum memenuhi standar pengungkapan yang ada, terbukti dari hasil penghitungan pengungkapan, laporan keuangan pemerintah kota manado mengungkapkan 18 item pengungkapan, atau dapat dikatakan lebih dari setengah total item pengungkapan yaitu 34 item pengungkapan, dan masih ada 16 item pengungkapan yang belum diungkapkan oleh pemerintah kota manado, hal ini menunjukan bahwa laporan keuangan pemerintah kota manado belum sepenuhnya mengungkapkan item pengungkapan yang sesuai Standar Akuntansi Pemerintahan. Dari penelitian ini juga didapati persentase pengungkapan laporan keaungan pemerintah kota manado adalah sebesar 52,94\%. Adapun kurangnya pengungkapan tersebut dikarenakan pada tahun 2015 karena penerapan peraturan yang berlaku masih dalam proses penyesuaian peralihan dari basis kas menuju akrual menurut PP No.24 Tahun 2005 ke basis akrual PP. No. 71 Tahun 2010.

\subsection{Saran}

Setelah melihat hasil penelitian ini, diharapkan pemerintah kota manado lebih baik lagi dalam pengungkapan laporan keuangan, dengan cara mengikuti peraturan yang ada, serta membuat pengaturan lebih lanjut mengenai seberapa luas informasi yang harus diungkapkan atau informasi prioritas yang menjadi keharusan dan informasi mana yang dianjurkan. Selain itu pemerintah juga perlu memperbaharui pengeturan lebih lanjut tersebut untuk dapat disesuaikan dengan peraturan perundang - undangan yang ada.

\section{DAFTAR PUSTAKA}

Adhariani, Rini. 2014. Opini Audit Dan Pengungkapan Atas Laporan Keuangan Pemerintah Kabupaten Serta Kaitannya Dengan Korupsi Di Indonesia. Jurnal. Etikonomi. Universitas Islam Negeri Syarif Hidayatullah Jakarta. Vol 13, No.1.

Arifin, Johan. 2013. Fiscal Policy Disclosure In Indonesian Local Governments. Jurnal. Jurnal Akuntansi \& Auditing Indonesia (JAAI). Vol 17, No.1.

Budiarso, N. S. 2018. Testing of Agency and Stewardship Theories on Financial Accountability in Sulawesi Region, Indonesia. Jurnal. International Journal of Finance and Accounting. Vol 7, No.1.

Setiono, Bambang. 2016. Financial report and public accountability culture in Indonesia. Jurnal. Jurnal Akuntansi \& Auditing Indonesia. Vol 20, No.1. 
Susilo, Eko. 2015. Analisis Pengungkapan (Disclosure) Laporan Keuangan Kabupaten Yang Meraih Opini Audit Wajar Tanpa Pengecualian (WTP) Dua Tahun Berturut - Turut. Jurnal Akuntansi. Vol. 3, No. 2.

Kema, Ihwan. 2013. Penyajian Laporan Keuangan Daerah Berdasarkan Standar Akuntansi Pemerintahan Pada Pemerintah Kota Manado. Jurnal. Universitas Sam Ratulangi. Volume 1, Nomor 3.

Izzati, Aatina. 2017. Determinan Pengungkapan Laporan Keuangan Pemerintah Daerah Di Indonesia. Jurnal. http: // digilib. unila. ac.id/ view/ divisions/ Akuntansi-S2/ 2017.default.html. Diakses tanggal 25 April 2018 pukul 9:26 WITA.

Mursyidi. 2013. Akuntansi Pemerintahan di Indonesia. Refika Aditama. Bandung.

Peraturan Pemerintah Nomor 71 Tahun 2010. Tentang Standar Akuntansi Pemerintahan berbasis Akrual.

Pontoh, Winston. 2013. Akuntansi Konsep dan Aplikasi. Halaman Moeka. Jakarta www.speednewsmanado.com, diakses tanggal 24 April 2018 pukul 13:04 WITA 